\title{
РОССИЙСКИЙ РЫНОК ТРУДА В УСЛОВИЯХ COVID-19: АНАЛИЗ, ОЦЕНКА, ПЕРСПЕКТИВЫ
}

\author{
(c) 2021 Подвойский Глеб Львович \\ кандидат экономических наук, \\ ведущий научный сотрудник Центра политики занятости и трудовых отношений \\ Институт экономики Российской академии наук, Россия, Москва \\ E-mail: e.a.yurovskaya@gmail.com
}

Актуальность публикации определена дестабилизацией национальных рынков труда практически всех стран мира в результате жестких и масштабных мер противодействия пандемии Covid-19, которые создали принципиально новую реальность. Предметом исследования выступают основные показатели международного и российского рынка труда, новые тенденции его развития. Цель работы: выявить основные проблемы и направления трансформации рынка труда, меры по его восстановлению, реформированию государственной службы занятости, совершенствованию трудового законодательства. Источниками информации стали российские и зарубежные научные публикации, социологические и специализированные исследования, а также официальные данные органов государственной власти. В ходе исследования использовались общенаучные методы контент-анализа, синтеза, сопоставления, комплексного подхода и иные методы познания. Научная новизна исследования обусловлена предлагаемым широким подходом к анализу тенденций и перспектив российского рынка труда. Представлены показатели безработицы в 2020-2021 годах, в том числе на предприятиях малого и среднего предпринимательства (МСП), а также различные аспекты неформальной занятости. Особенность российского рынка труда состоит в том, что работодатели во время экономических кризисов предпочитают не увольнять работников, а сокращать рабочее время и заработную плату, чтобы избежать массовых увольнений и сохранить персонал. Подведены некоторые итоги выполнения принятого российским правительством в октябре 2020 года общенационального плана действий по восстановлению занятости и доходов населения, росту экономики, а также долгосрочным структурным изменениям. Сделан вывод о том, что оперативные меры, принятые органами исполнительной власти для стабилизации ситуации на рынке труда, не позволили допустить масштабного взрыва безработицы в стране. Однако сдерживание безработицы традиционным для России способом сокращения издержек приводит к снижению заработной платы и вознаграждений работников и ухудшению социально-экономической ситуации в стране. Показано влияние цифровизации и новых технологий на рынок труда, а также развитие дистанционной (удаленной) работы и платформенной занятости. С февраля 2020 года в России отмечен резкий рост спроса на удалённую работу, что потребовало с 1 января 2021 года скорректировать трудовое законодательство. Обсуждаются основные аспекты масштабной реформы государственной службы занятости, начатой министерством труда в 2021 году в рамках национального проекта «Производительность труда». Реформа предполагает трансформацию центров занятости в государственные кадровые агентства и создание единой информационной платформы для всех центров занятости страны. Даны рекомендации по совершенствованию законодательства в сфере занятости. Дальнейшая работа с целью построения единого, открытого и прозрачного рынка труда в России должна строиться на основе глубокого анализа, который позволит минимизировать новые вызовы и риски в условиях продолжающейся пандемии и новой технологической революции.

Ключевые слова: пандемия Covid-19, безработица, дестабилизация рынка труда, трудовые доходы, неформальная занятость, цифровизация рынка труда, реформа государственной службы занятости, совершенствование трудового законодательства. 
Пандемия коронавирусной инфекции COVID-19 и различные по степени жесткости ограничительные меры по ее сдерживанию оказали крайне негативное воздействие на социально-экономическое положение большинства стран мира.

В докладе Всемирного банка (ВБ) «Перспективы мировой экономики», опубликованном в июне 2020 года, прогнозируется, что спад в мировой экономике в этом году составит $5,5 \%$, и он будет самым глубоким со времен Второй мировой войны [15].

В этих условиях национальные рынки труда пережили серьезные потрясения, следствием которых стала их дестабилизация. Принятые в большинстве стран мира противопандемийные меры в виде физического дистанцирования, ограничения свободы передвижения, а также карантина или самоизоляции вызвали массовую приостановку или закрытие компаний и предприятий, прежде всего малого и среднего предпринимательства (МСП). Это привело к резкому сокращению уровня занятости и доходов населения, снижению спроса на товары и услуги.

По оценке экспертов Международной организацией труда (МОТ), в общей сложности $94 \%$ работников в мире, по данным на сентябрь 2020 года, проживали в странах, где действовали те или иные режимы закрытия рабочих мест. Их доля достигла максимума 97\% (данные на апрель 2020 г.), затем медленно снижалась до середины июля того же года, после чего снова начала немного расти [4].

В России пандемия COVID-19 в мае 2020 года затронула порядка 4,17 млн. компаний и индивидуальных предпринимателей (ИП) от общего числа 6,05 млн., то есть до 67\% малых, средних и крупных предприятий и ИП. Падение выручки МСП более чем на 30\% наблюдалось в 65 классах ОКВЭД из 88 существующих.

По данным мониторинга «Мнение малого и среднего бизнеса о мерах государственной поддержки в период эпидемии коронавируса», проведенного в мае 2020 года Институтом уполномоченного при президенте России по защите прав предпринимателей [5] получены результаты, приведенные на рис. 2.

\section{Всплеск безработицы в 2020 году}

Ситуация на российском рынке труда в декабре 2019 года, когда была впервые зафиксирована вспышка ставшей глобальной пандемии коронавирусной инфекции COVID-19, выглядела вполне благополучной. По данным Минтруда России, численность безработных в возрасте 15 лет и старше составляла 3,5 млн. человек $(4,6 \%)$, а в органах службы занятости зарегистрировались 691 тысяча человек. В то же время работодатели заявили о почти 1,5 млн. свободных рабочих мест и вакантных должностей ${ }^{*}$.

Необходимо пояснить, что в последние годы регистрируемая службой занятости России без-

* URL: https://mintrud.gov.ru/ministry/programms/inform/2

\section{Сокращение мирового объема} трудовых доходов за первые три квартала 2020 года по сравнению с тем же периодом 2019 года (без учета мер по поддержке доходов, принятых государствами)

на 10,7\%, или на 3,5 трлн долларов США
Общие предполагаемые потери рабочего времени во втором квартале 2020 года (по сравнению с четвертым кварталом 2019 года)

$17,3 \%$, что эквивалентно полному рабочему времени 495 млн работников
Ожидаемые потери рабочего времени (согласно базовому сценарию) в четвертом квартале 2020 года

$8,6 \%$, или 245 миллионов рабочих мест

Оценки потерь трудовых доходов (без учета мер поддержки доходов) предполагали общемировое снижение на 10,7 \% в течение первых трех кварталов 2020 года (по сравнению с соответствующим периодом 2019 года), что составило 3,5 триллиона долларов США, или 5,5 \% мирового валового внутреннего продукта (ВВП) за первые три квартала 2019 года 
53,3\% компаний характеризуют свое положение как «кризис» и «катастрофа»

$62,2 \%$ оценивают шанс выживания ниже $50 \%$

на текущий момент деятельность приостановлена у $35,7 \%$ компаний, на пике карантина не работало $56,1 \%$ компаний

$55,6 \%$ компаний отметили, что спрос сократился на $50 \%$ и более

ключевые трудности - невозможность платить заработную плату $(52,4 \%)$, аренду и налог на имущество $(42,8 \%)$

большинство компаний не сократили сотрудников, но снизили ФОТ $(60,88 \%)$ и отправили сотрудников в отпуск за свой счет $(57,6 \%)$

Puc. 2

работица была в четыре-пять раз ниже общей безработицы, рассчитываемой Росстатом по методологии МОТ. Методология МОТ учитывает не только официально зарегистрированных безработных, но и всех фактически незанятых старше 15 лет, которые тем или иным способом занимались поиском работы в течение последних четырех недель и готовы сразу приступить к трудовой деятельности. Для этого Росстатом РФ регулярно проводятся опросы около 70 тысяч человек.

Ключевой индикатор рынка труда - уровень занятости - последние двадцать лет в России оценивается как один из самых высоких в мире. Обычно он слабо реагировал даже на сильные макроэкономические колебания, как положительные, так и отрицательные. После кризиса 20082009 годов, когда был короткий всплеск общей безработицы (максимум до 8,2\%), занятость снова быстро выросла (ниже 6\% к 2012 году) и оставалась стабильно высокой, несмотря на замедление темпов роста ВВП, перешедшее затем в рецессию [13].

После принятия в марте 2020 года ограничительных и запретительных мер, связанных с пандемией, общая безработица в августе этого же года выросла на треть до 4,8 млн. человек (6,4\%). Она превысила 6\% впервые с марта 2012 года. В службах занятости были зарегистрированы 3,6 млн. человек, то есть зафиксирован рекордный рост регистрируемой безработицы более чем в пять раз. Из их числа 3,4 млн. человек получали пособие по безработице.
Столь резкое падение уровня официально регистрируемой занятости объясняется тем, что российское правительство упростило процедуры приобретения статуса безработного, переведя этот процесс в режим онлайн, а в конце марта 2020 года увеличило максимальный размер пособия по безработице до уровня МРОТ (12,13 тыс. руб.), а минимальный - до 4,5 тыс. руб. Однако к 1 декабря число людей, стоящих на учете в службе занятости, сократилось до 3,2 млн., поскольку правительство с 1 октября 2020 года ограничило круг получателей пособия в размере МРОТ.

Кроме того, правительство назначило безработным выплату в размере 3 тысяч рублей в месяц на каждого несовершеннолетнего ребёнка. По заявлению исполкома Конфедерации труда России (КТР), такое решение фактически лишает права на пособия граждан России, привлеченных к труду без оформления трудовых отношений. В результате люди, оставшиеся без работы, но не способные подтвердить факт формального увольнения, лишаются всякой поддержки. При этом последствия пандемии бьют, прежде всего, по отраслям, в которых преобладает неформальная занятость.

После первой волны пандемии, по данным компании «HeadHunter Group», в наибольшей степени пострадали сферы туризма, гостиничный бизнес и рестораны (количество вакансий упало на 78\% по сравнению с февралем), спорта, фитнеса и салоны красоты (73\%), услуг для населения (68\%), искусства, развлечений и масс-медиа (64\%), маркетинга и рекламы (54\%)*.

\footnotetext{
*https://hh.ru/article/27176
} 
Как и туризм, событийная индустрия (Event Industry), охватывающая весь спектр услуг по проведению деловых выставок, конгрессов, фестивалей, спортивных мероприятий и т.д., одной из первых ощутила на себе последствия пандемии из-за вынужденной отмены и переноса мероприятий*.

Помимо сектора услуг, в 2020 году из-за антипандемийных ограничений в наибольшей степени пострадали выпускники вузов и ссузов, самозанятые, теневые и неформальные работники ${ }^{* *}$

По мере смягчения ограничений в сентябре 2020 года началось постепенное повышение уровня общей занятости, взрывного роста официальной безработицы в России не произошло.

Ряд независимых экспертов считают официальную статистику Росстата по безработице заниженной примерно в два раза. Например, аналитики международной аудиторско-консалтинговой сети FinExpertiza подсчитали, что во втором квартале 2020 года число безработных в России достигло 9,3 млн. человек $-12,1 \%$ от экономически активного населения страны, что в два раза больше официальных данных Росстата. Эта сумма складывается таким образом: в апреле-июне 2020 безработными были 4,47 млн. человек (6\% рабочей силы), еще 4,87 млн. россиян $(6,1 \%$ рабочей силы) тоже не были трудоустроены, но хотели бы найти работу.

Однако Росстат не считал их безработными из-за несоответствия критериям МОТ, поскольку официально безработным признается тот, кто одновременно не имеет доходного занятия, ищет работу на протяжении последних четырех недель и готов приступить к ней в течение недели. Если брать в расчет переведенных на неполную занятость и отправленных в отпуск без зарплаты россиян, то количество фактически безработных оказывается еще выше **** $^{*}$.

С введением антипандемийных ограничительных мер с апреля 2020 г. ежемесячные опро- сы Росстата стали проводиться по телефону, что не гарантирует достоверного результата по реальному уровню безработицы.

Президент Конфедерации труда России (КТР) Борис Кравченко также выразил сомнение в точности публикуемой статистики Минтруда России по безработице, которая не отражает реальную динамику рынка труда. В июне 2020 года он заявил, что, по оценке КТР, общая численность официально безработных россиян составляла 8 млн. человек и вчетверо превышает количество зарегистрированных тогда в службах занятости. Статистика Минтруда России не видит тех, кто теряет работу и не уведомляет об этом государство ******.

По оценке экспертов НИУ ВШЭ, пандемия вывела в безработицу, вынужденный простой, неоплачиваемые отпуска и неполную занятость около 20 млн. человек ${ }^{* * * * * *}$.

За год пандемии в 2 раза выросло количество регионов с уровнем безработицы $10 \%$ и выше. В 2019 году таких регионов было 6, в 2020-13. Самая высокая безработица в Ингушетии (37\%), в Туве (22,3\%), в Чечне (21,7\%), в Северной Осетии (16,3\%), Дагестане (16,1\%), Кабардино-Балкарии $(15,4 \%)$. Самая низкая в ЯН АО $(2,5 \%)$, в Москве $(2,7 \%)$, ХН АО (3,2\%), Санкт-Петербурге $(3,6 \%)$ и на Камчатке (3,6\%). В 82 регионах уровень безработицы вырос, в 2-х - не изменился, а на Чукотке снизился на $0,1 \%$. Средний возраст безработного составил 35,6 года, доля молодежи до 25 лет $-21,8 \%$, старше 50 лет - 15,9\%. Из 4, 8 млн. безработных 1,4 составляли сельские жители. Дольше всего (от 1 до 3 месяцев) искали работу именно сельские жители. В состоянии застойной безработицы находилось 27,1\% сельских безработных и $14,7 \%$ городских.

Необходимо выделить две базовые проблемы структурной безработицы.

Первая заключается в том, что профессия, которой работники овладели 20 лет назад, сегодня может быть невостребованной и низко оплачиваемой. И только переобучение может решить

\footnotetext{
* https://www.tohologv.com/files/Hospitality/Industrv/2020/2020-04-09-covid 19 research russiacb/covid_ 19_ research russiacb.pdf

** https:/www.finam.ru/analvsis/n.ewsitem/glavnve-posledstviva-pandemii-dlva-rvnka-truda-bezrabotica-i-sprosna-novye-kompetencii-20201115-13000/

*** URL: https://www.vedomosti.ru/economics/news/2Q20/1.0/01 /84.1781 -analitiki-otsenili-realnuyu-bezrabotitsuv-rossii-v-dva-raza-vishe-ofitsialnoi

**** https://www.interfax.ru/mssia/711204

***** bttps://icef.hse.m/data/2020/06/15/1605032170/HSE Covid 05 2Q2Q.pdf

URL: https://rg.ru/2020/1l/12/vvzhutovich-massovvh-uvolnenii-vo-vseh-otrasiiah-skoree-vsego-ne-budet.html
} 
эту проблему.

Вторая проблема - территориальная безработица. Есть регионы, где существуют избыточные рабочие руки, а есть хронически дефицитные регионы. Только бизнес эту проблему решить не сможет. Необходима государственная программа для создания условий внутренней трудовой миграции.

В результате введения антипандемийных ограничительных мер изменилась система оценки общей безработицы по методологии MOT. C апреля 2020 ежемесячные опросы Росстата около 70 тысяч человек стали проводиться по телефону, что отрицательно повлияло на достоверность их результатов. Таким образом, данные Росстата по методологии МОТ и тем более Минтруда России по статистике служб занятости не дают полного представления о реальном уровне безработицы и ее структуре, это затрудняет разработку адресной и эффективной политики на рынке труда.

Сильное негативное влияние на российский рынок труда оказывает многократно возросшая неопределенность перспективы выхода из кризиса. Например, работодатели не могут решить, когда можно нанимать новых работников, а потребители - тратить или копить черный день. Такая неопределенность тормозит процесс восстановления экономики, хотя рынок труда постепенно адаптируется, но остается в зоне турбулентности.

\section{Адаптация рынка труда: российские осо- бенности}

По данным МОТ, во всем мире около 1,25 млрд. работников (около 38\% рабочей силы) заняты в секторах, подверженных высокому риску. В наибольшей степени негативным воздействием пандемии затронуты следующих четырех сектора, в которых зачастую заняты низкоквалифицированные работники:

- общественное питание и гостиничное хозяйство (144 млн. работников);

- розничная и оптовая торговля (482 млн.);

- предпринимательство и административная деятельность (157 млн.);

- обрабатывающая промышленность (463 млн.).

Во многих странах значимый вклад в ВВП и занятость прямо или косвенно вносит туристическая деятельность, которая обеспечивает около 10 процентов всех рабочих мест. Однако с началом кризиса, вызванного COVID-19, международный туризм практически прекратился.

В непропорционально высокой степени пострадали предприятия МСП и микропредприятия, на которых занята большая часть рабочей силы в мире. Нельзя забывать и около 2 млрд. работников, занятых в неформальном секторе экономики, которые в силу своей незащищенности могут оказаться на грани выживания [1].

Россия в целом вписывается в эту картину, но российский рынок труда имеет свои особенности. Например, в российской экономике доля МСП в общей занятости более чем в два раза ниже, нежели в большинстве развитых стран, поэтому реакция важнейших макроэкономических показателей (ВВП, безработица и инфляция) на ограничительные меры сравнительно невысокая*.

В отличие от многих стран мира в России за последние 20 лет все экономические кризисы слабо влияли на уровень занятости в силу того, что работодатели предпочитают не увольнять работников, а сокращать рабочее время и заработную плату. В кризисные периоды власти и работодатели сокращали издержки и делали все возможное, чтобы избежать массовых увольнений и сохранить персонал.

И в 2020 году российский рынок труда адаптировался привычным способом снижения издержек. Сокращение рабочего времени проводилось путем перевода на неполный рабочий день или неделю, введения вынужденных отпусков за свой счет, либо с частичной компенсацией и т.д., что приводило к снижению заработной платы и вознаграждений. Работники и на это раз предпочли сохранить свои рабочие места при сокращении заработной платы.

В результате, по данным Росстата, реальные располагаемые денежные доходы населения во втором квартале 2020 года упали сразу на 8,4\% в годовом выражении, что стало рекордом в XXI веке, в третьем квартале они продолжили сокращение и снизились почти на $5 \%$.

Затяжной спад денежных доходов россиян в долгосрочной перспективе будет сдерживать выход российской экономики из стагнации, полагает директор Института социального анализа и прогнозирования РАНХиГС Татьяна Малева [14].

Можно сделать вывод, что такое сдерживание безработицы традиционным для России способом приводит к ухудшению социально-

*https://www.rbc.ru/economics/19/1l/2Q2Q/5fb52dac9a7947234c4d28dl 
экономической ситуации в стране. В западных странах также существует подобная практика, но гораздо в меньших масштабах, а падение доходов уволенным или сокращенным работникам компенсирует государство, в том числе прямыми выплатами - «вертолетными деньгами».

В период пандемии в России рассматривали возможность применения «вертолетных денег», как способа проведения денежно-кредитной политики, однако глава Банка России Эльвира Набиуллина в апреле 2020 года заявила, что этот инструмент для России совершенно не актуален ${ }^{*}$.

Неформальная занятость: трудности учета

Одна из проблемных зон российского рынка труда - неформальная занятость - увеличивалась из года в год в течение последних 15-20 лет за редкими исключениями, например, после кризиса 2008-2009 годов. Однако с 2017 года наблюдается ее небольшое снижение. Этим Россия отличается от развитых стран, где по мере роста экономики сокращается неформальная занятость ${ }^{* * *}$.

Оценки масштабов неформальной занятости совершенно разные. Это вызвано терминологической путаницей. Росстат на основе рекомендаций МОТ выделяет три вида неучтенной деятельности: скрытая (или теневая), неформальная и нелегальная. Эти термины на практике обозначают довольно близкие по смыслу и часто пересекающиеся явления, но несколько различаются между собой.

Скрытая (или теневая) экономическая деятельность в большинстве случаев считается законной, но при этом скрывается или преуменьшается с целью уклонения от уплаты налогов, социальных взносов или выполнения определенных административных обязанностей, или предписаний по охране труда, выполнению санитарных и других норм. Примером этой деятельности может служить подпольное производство алкоголя.

Неформальная экономическая деятельность также осуществляется в основном на законном основании самозанятыми и индивидуальными производителями или так называемыми некорпорированными предприятиями, которые принадлежат отдельным лицам или домашним хозяйствам и часто не оформляются в установ- ленном порядке. В России значительное распространение неформальное производство имеет в сельском хозяйстве, торговле, строительстве, сфере услуг и некоторых других отраслях.

Нелегальная экономическая деятельность является незаконной, т.е. она охватывает те виды производства товаров или услуг, которые прямо запрещены существующим законодательством (производство и продажа наркотиков, оружия, проституция, контрабанда и т.д.) [11].

В различных исследованиях и документах эти термины нередко заменяются или путаются. Например, неформальную занятость называют серой теневой или просто теневой, а нелегальную - черной теневой и т.д. Росстат с 2006 года публикует данные только по неформальной занятости.

Численность занятых в неформальном секторе в 2006 году (более ранних данных Росстат не публикует) составила 12,6 млн. человек, а в 2019 выросла до 14,8 млн., хотя немного снижалась после кризиса 2008-2009 годов [13].

К середине 2019 года доля работающих неофициально, по оценке Росстата, достигла 15,25 млн. человек (21,3\%). Эксперты связывают это с сокращением малого бизнеса и миграцией предпринимателей в ИП или в самозанятые ${ }^{* * * *}$.

Точное представление о неформальном секторе занятости методом опросов получить практически невозможно, поскольку далеко не все опрошенные отвечают правдиво. При этом Росстат не учитывает скрытую (или теневую) занятость, например, тех, кто на зарегистрированных предприятиях получают серую зарплату (всю или ее часть) в конвертах и не имеют трудовых договоров. Поэтому в данной статье понятия неформальной, скрытой или теневой занятости не различаются по своему содержанию.

Исследованиями неформальной занятости занимается не только Росстат. Например, по данным опроса, проведенного в мае 2019 года научно-исследовательским Центром социальнополитического мониторинга Института общественных наук РАНХиГС, 32,5\% занятого населения России (около 25 млн. человек) в той или иной форме причастны к теневому рынку труда. В опросе приняли участие 1215 человек из 27 субъектов РФ, занятых на предприятиях различных форм собственности основных видов экономической деятельности с учетом социально-

\footnotetext{
* https.7/rg.ru/2020/04/17/bank-rossii-otkazaM

** https://www.hse.ru/news/1163625/115839875.html

*** https://www.rbc.ru/economics/05/09/2019/5d6e74fb9a7947Q9eeba4Kc
} 
демографических характеристик.

Установлено, что доля работников, занятых в различных формах на рынке труда неофициально в течение одного года (в \% от общего количества занятого населения), снизилась на $12.3 \%$ по сравнению с данными аналогично опроса 2017 года, когда она доставляла 44,8\%. Авторы предположили, что это обусловлено снижением потребительской активности граждан, которые в значительной степени становятся заказчиками неформальных работ или услуг

Количество работников, для которых неоформленная занятость стала основным источником дохода, характеризуется следующими данными: в 2013 году на это указали 11,9\% занятого населения, в 2017-13,6\%, в 2019-13,1\%.

Парадоксально, но количественное снижение уровня участия в теневой экономической деятельности сопровождается ростом положительного к ней отношения опрошенных работников. Так, с 50,8\% в 2017 году до 72,9\% в 2019 выросла доля тех, кто положительно относится к работам с получением оплаты «из рук в руки», минуя кассу в обход закона.

Кроме того, более половины опрошенных работников считают, что неофициальная экономическая деятельность в целом приносит больше пользы для общества, хотя некоторые признают и пользу, и вред в равной мере*.

Ограничительные меры по борьбе с пандемией ускорили тенденцию к снижению неформальной занятости в России. По данным опроса РАНХиГС, в 2020 году о теневой занятости (включая разовую) сообщили 28\% занятого населения, в то время как в 2019 году их доля достигала 32,5\% (в 2013 году - 44,5\%).

Доля тех, кто постоянно работает неофициально, в 2020 году сократилась на 3,8 процентного пункта, до 20,5\%, а доля заявивших неофициальный доход по основной и единственной занятости, составила 11,3\% (в 2019-13,1\%).

В 2020 году продолжилось падение спроса на неформальные услуги, пользоваться которыми люди стали несколько реже. Если в 2006 году граждане оплачивали «из рук в руки» примерно 2,2 услуги или работы в течение календарного месяца, то в 2020 году - 1,8. Общие расходы домохозяйств на оплату только наиболее распро- странённых услуг или работ, предоставляемых, как правило, самозанятыми гражданами неофициально, в 2020 году составили 4,1 трлн. руб. в год (в 2013 году -5 трлн. руб.).

По оценке экспертов РАНХиГС, сокращение объема неформальной занятости может быть вызвано как сложной эпидемиологической ситуацией из-за коронавируса, усложняющей предоставление неформальных услуг, так и активностью государства по обелению рынка труда и ограничению участия граждан в теневой деятельности (снижение налоговой нагрузки для самозанятых, невозможность получения господдержки пострадавшим от пандемии неформальным сектором экономики) $)^{* * * *}$.

Размер неформального сектора на рынке труда можно оценить косвенным образом. По данным Пенсионного фонда России (ПФР), в 2019 году страховые взносы в ПФР перечисляли лишь 54 млн. человек. Из 81,3 млн. трудоспособных россиян (старше 16 лет), по оценке директора Центра конъюнктурных исследований ВШЭ Георгия Остапковича, можно вычесть около 10 млн. неработающих домохозяек, студентов, инвалидов и т.д. Получается 70-72 млн. человек реально работающих, поэтому к неформальному сектору, по его мнению, относятся примерно 18 млн. россиян.

По его оценке, сумма скрытых финансовых потоков граждан, с которых не уплачиваются налоги, может достигать 12 трлн. рублей в год. Ежегодно бюджеты недополучают примерно 5,16 трлн. рублей подоходного налога и страховых взносов. Это около четверти доходной части федеральной казнын**.

Глава Счетной палаты РФ Татьяна Голикова в 2017 году сообщила, что 14,4 млн. россиян находятся для государства в тени и не платят налоги, хотя государство оплачивает их социальное обеспечение.

Минтруд России тогда подтвердил, что до 15 млн. человек могут быть отнесены к теневому сектору экономики. В 2015 году это ведомство подсчитало количество россиян трудоспособного возраста, за которых не поступают страховые взносы во внебюджетные фонды (Фонд социального страхования, Фонд обязательного медицинского страхования и ПФР) $)^{* * * * * *}$.

\footnotetext{
* https://social.ranepa.ru/novosti/item/sociologi-ranhigs-tret-rossivan-prichastna-k-tenevomu-rynku-truda

** https://www.kommersant.ru/doc/4613871?from=four economic

*** https://www.finanz.ru/novosti/aktsii/pochti-20-millionov-rossiyan-ushli-rabotat-v-ten-1028216689

***** https://iz.ru/news/669063
} 


\section{Меры по восстановлению экономики и рынка труда}

Беспрецедентная по скорости и масштабу турбуленция экономики и рынка труда в результате пандемии коронавируса (COVID-19) потребовала принятия срочных мер органами исполнительной власти. Для преодоления критической ситуации с весны 2020 года вводились запретительные и ограничительные меры разной степени жесткости.

Правительством РФ сразу после введения карантинных ограничений оперативно поддержало бизнес: отсрочена плата по кредитам, налогам и социальным взносам, аренде имущества. Также были временно запрещены проверки предприятий МСП, продлены лицензии и разрешительные документы. Малому, среднему бизнесу и системообразующим предприятиям предложены льготные кредиты, в том числе на зарплату по ставке 2\% с возможностью списания.

Однако большинство мер поддержки МСП, принятых российским правительством в 2020 году, не дали желаемых результатов, поскольку они лишь отсрочили обязательные платежи на несколько месяцев, к тому же они были труднодоступными. Это не позволило более существенно уменьшить последствия вынужденного закрытия или простоя предприятий МСП из-за снижения спроса, что стало дополнительным стимулом их перехода в неформальный сектор [9].

Правительство долго разрабатывало списки нуждающихся компаний и предприятий, а также методики распределения помощи, хотя они должны были быть готовы заранее на случай непредвиденных или форсмажорных обстоятельств.

В июне 2020 года подготовлен и в октябре принят общенациональный план действий по восстановлению занятости и доходов населения, росту экономики, а также долгосрочным структурным изменениям.

План разделен на три этапа:

- июнь-сентябрь 2020 - стабилизация, чтобы не допустить дальнейшего падения доходов населения, и адаптацию наиболее пострадавших отраслях;

- октябрь 2020-июнь 2021 - восстановление роста экономики и доходов граждан до уровня 2019 года;

- июль-декабрь 2021 - активный рост эко- номики и реальных доходов населения.

В плане более 500 мероприятий, рассчитанных до конца 2021 года, многие из них уже выполнены в 2020 году. На их финансирование выделено более 6,4 трлн. рублей, более 4 трлн. из них (3,9\% ВВП) потрачено в прошлом году. План будет считаться достигнутым, если к концу 2021 года уровень безработицы упадет ниже 5\%, а рост ВВП составит не менее 3\% в год*.

В качестве помощи высвобождаемым работникам Минтруд России в мае 2020 года предложил организовать временные общественные работы там, где это не ухудшит ситуацию с распространением коронавируса, с частичной компенсацией организовавшим такие работы предприятиям затрат на оплату труда.

Правительство в июле 2020 года решило направить регионам более 4 млрд. рублей из своего резервного фонда на частичное возмещение расходов по оплате труда сотрудников при создании временных рабочих мест. Гражданам, которые обратились в службы занятости, а также безработным предложили трудоустройство в строительстве, агропромышленном комплексе, в сфере транспорта, в ЖКХ, на благоустройстве территорий, а также в социальных службах по уходу за пожилыми людьми. Кроме того, на предприятиях, где сотрудников перевели на неполную занятость, можно было организовать дополнительную временную работу. Такие меры позволили до конца года временно трудоустроить более 80 тысяч человек**.

В целях стабилизации рынка труда в 2020 году правительство также выделило 3 млрд. рублей на переобучение россиян, потерявших работу из-за ситуации с пандемией коронавируса.

Для более оперативной оценки ситуации на рынке труда в 2020 году был налажен онлайнмониторинг на портале «Работа в России», куда стали поступать данные пока только от предприятий, на которых заняты более 21 млн. работников (около 40\% от общего числа всех трудоустроенных граждан) $)^{* * * *}$.

Показатель уровня безработицы в России, согласно проекту федерального бюджета на 2021-2023 годы, вернется к «естественному» уровню ниже 5\% к концу 2021года. При этом Минэкономразвития России прогнозирует, что безработица в стране по итогам 2020 года составит 5,7\%, затем ожидается ее снижение до 5,2\%

\footnotetext{
* https://rR.ru/2020/09/Z9/pravitelstvo-utverdilo-obshchenacionalnyi-plan-vosstanovleniia-ekonomiki.html

** http //gov eminent. ru/ne ws/3 9970/

**** https://mintrud.gov.ru/emplovment/59
} 
в 2021 году, 4,7\% в 2022 году и 4,6\% в 2023 году. Однако наблюдаемые негативные изменения на рынке труда гораздо глубже официальных оценок, поэтому прогнозные ожидания по ряду показателей представляются слишком оптимистичными*.

На темпы восстановления экономики и рынка труда главным образом влияют динамика заболеваемости коронавируса (COVID-19) и меры по ее сглаживанию - самоизоляция, социальное дистанцирование, переход на удаленную работу и обучение, остановка или ограничение работы части предприятий и организаций. Процесс восстановления занятости в отдельных отраслях российской экономики идет с разной скоростью. По данным экспертов ВШЭ, самые тяжелые последствия пандемийных ограничений ощутила сфера услуг, где занято около 20 млн. человек из 72 млн. официально работающих граждан. Восстановление спроса в этой сфере ожидается не ранее 2022 года**.

Российское правительство видит выход из кризисной ситуации в восстановлении платежеспособного спроса. Однако проблема состоит в том, что с марта 2020 года накопился огромный спрос, особенно в сфере услуг (туризм, гостинично-ресторанный бизнес, индустрии спорта, красоты, развлечений и т.д.), который просто невозможно реализовать из-за пандемийных ограничений. Поэтому сроки стабилизации рынка труда в той или иной сфере точно предсказать невозможно.

Технологический отбор на смену естественному

В октябре 2020 года опубликован доклад Всемирного экономического форума (ВЭФ) «Будущее рынка труда». Авторы доклада прогнозируют, что к 2025 году роботизация приведет к исчезновению 85 млн. рабочих мест, но появится 97 млн. новых в результате изменения отношений между машинами, алгоритмами и человеком на рынке труда [3].

Технологическая безработица в меньшей степени грозит России из-за стагнации экономики и падения инвестиций в последние годы. Однако структура рынка труда постоянно меняется, с разной скоростью исчезают одни профессии, но появляются новые.
Пандемия коронавируса (COVID-19) резко активизировала появление и применение прорывных разработок в сфере искусственного интеллекта (ИИ), роботизации и информационнокоммуникационных технологий (ИКТ).

Особенно быстро процесс цифровизации, по мнению экспертов ВЭФ, отмечен в таких областях, как облачные технологии, обработка больших массивов данных (Big data), интернет-торговля, шифрование, разработка дронов и негуманоидных роботов.

Шоковая цифровизация заметно ускорила формирование новой реальности во всех сферах жизни, в том числе серьезно влияет на рынок труда. Работодатели в целях оптимизации издержек начали более широко использовать возможности цифровизации, переводить бизнеспроцессы на аутсорсинг и часть сотрудников на дистанционную работу, привлекать фрилансеров как индивидуальных предпринимателей (ИП) или самозанятых.

В октябре 2019 года Минфин России рассчитал, что к 2024 году количество самозанятых граждан, зафиксировавших свой статус с учетом введения для них налогового режима, увеличится до 2,4 млн. по сравнению с 200 тысяч в 2019 году. В 2020 году их станет в 4 раза больше -800 тысяч, в 2021 году $-1,4$ млн., в 2022 году $-1,8$ млн., в 2023 году $-2,1$ млн.****

Однако из-за пандемии число зарегистрированных самозанятых стало расти гораздо более высокими темпами, и уже к концу августа 2020 года их стало около 1 млн. человек с суммарным доходом более 130 млрд. рублей. ФНС привела самые популярные среди них профессии: перевозка пассажиров (16\%), строительство (8,6\%), консультирование (7,1\%), сдача квартир в аренду (7\%), услуги по доставке (6,1\%). Средний возраст самозанятых - 30-40 лет

Долгосрочное влияние пандемии на рынок труда в России может оказаться одним из самых существенных в сравнении с ситуацией в других странах. Вынужденный переход к удаленной работе позволяет работодателям выбирать сотрудников из гораздо большего числа кандидатов по всей стране. Многие российские компании намерены перейти к комбинированной или полностью дистанционной модели работы после

\footnotetext{
* https://tass.ru/ekonomika/9498117

** https://expert.ru/2020/07/24/ryinok-truda/

**** http: /www. fmmarket. ru/news/5089448

**** https://www.vedomosti.ru/partner/articles/2020/10/13/842984-pochemu-kompanii
} 
пандемии*.

Это дает больше возможностей для трудоустройства специалистам из регионов, которые при дистанционной работе могут претендовать на работу в крупных компаниях, в том числе столичных. В России работники так же часто, как и во многих странах, меняют место и характер работы, но гораздо реже уезжают в другие регионы в поисках работы. Удаленная занятость позволит повысить пространственную мобильность и улучшить этот показатель российского рынка труда**.

Спрос на удалённую работу в РФ растёт с февраля 2020 года. Самыми популярными профессиями в дистанционном формате стали программисты, педагоги, онлайн-репетиторы, продюсеры, менеджеры по продажам и работе с

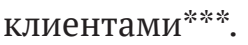

Растет и количество вакансий, предполагающих удаленную занятость. По данным HeadHunter, больше всего их предлагают в отраслях телекоммуникаций, продаж, административного персонала, в маркетинге, науке, образовании и консультировании ****.

Авторы доклада ВЭФ «Будущее рынка труда» считают, что в мире к 2025 году наиболее востребованными станут специалисты по ИИ, большим данным и машинному обучению. При этом снизится спрос на рядовых сотрудников бухгалтерии, юристов, секретарей администраторов, а также наборщиков данных [3].

По данным совместного исследования сервиса «Работа.ру» и «Сбериндекса», проведенного в декабре 2020 года, составлен список наиболее востребованных профессий на рынке в 2021 году. В него вошли медработники, фармацевты, специалисты IT-области и профессии сферы услуг

В перспективе 5-10 лет негативные последствия пандемии, изменения спроса на рынке труда могут затронуть офисных работников, средних менеджеров-управленцев, юристов, диспетчеров, водителей, охранников, владельцев офисных центров

В долгосрочной перспективе, по данным Института профессиональных квалификаций, вырастет спрос на следующие профессии:

- Помощники по уходу, сиделки, соцработники в различных сегментах экономики ухода (care economy), поскольку после пандемии коронавируса люди будут больше заботиться о здоровье собственном и всей семьи.

- Специалистов по диджитализации процессов, программисты, SMM и контентменеджеры и всех, кто может работать удаленно.

- Психологи после самоизоляции будут востребованы больше обычного.

- Специалисты по бытовым услугам - сантехники, сборщики мебели, фотографы.

- Организаторы виртуальных бизнестуров, консультанты по оптимизации бизнеспроцессов онлайн [12].

Эксперты НИУ ВШЭ обращают внимание на начавшийся процесс массового вытеснения работников рутинного умственного труда. Если в предыдущие кризисы на рынке труда снижался спрос и росла безработица, то сейчас наблюдается спад предложения из-за нехватки работников требуемой квалификации. Организация общественных работ эту проблему не решает $* * * * * * *$.

Автоматизации и цифровизации увеличивают спрос на креативных специалистов с развитыми «мягкими навыками» (soft skills). Это надпрофессиональные навыки, например, адаптивность, умение работать в команде, позитивный взгляд на мир, креативность, лидерство, этика и т.д. ${ }^{*} * * * * * * * *$

По мнению экспертов ВЭФ, в результате изменений на рынке труда заметно вырастет спрос на такие способности и навыки сотрудников, как критическое мышление, готовность и умение разрешать проблемы, способность к самоорганизации, самоуправлению, к постоянному обучению и работе в условиях стресса [3].

\footnotetext{
* https://www.forbes.ru/newsroom/biznes/410525-sovershenno-novaya-realnost-ft-ocenila-vliyanie-pandemiina-rynok-truda-v

** https://www.kommersant.ru/doc/4134738

**** https://news.ru/eeonomics/koliehestvo-udaIyonnyh-vakansij-v-rl-vyrosIo-па-71/

***** https://rg.ru/2020/11/15/kak-izmenilsia-ivnok-truda-v-2020-godu.html

****** https://tass.ru/ekonomika/10306887

******* https://www.ftnam.m/analysis/newsitem/glavnye-posledstviya-pandemii-dlya-rynka-truda-bezrabotica-ispros-na-novye-kompetencii-20201115-13000/

********* https://moslenta.ru/urbanistika/rabotu-potervayut-milliony-kakoi-udar-naneset-pandemiya-830407.htm

********* https://www.fmam.ra/analysis/newsiter^ bezrabotica-i-spros-na-novye-kompetencii-20201 j 15-13000/
} 
При этом такие некогнитивные свойства личности, как открытость новому, добросовестность, дисциплина, эмоциональная устойчивость, необходимы для успешного обновления когнитивных навыков в ходе дополнительного обучения и переобучения [7, 8].

Все большей популярностью у работодателей пользуются работники, способные выполнять несколько функций, заменяя двух-трех специалистов.

Меняется и система набора кадров, в частности резко выросло число собеседований, проводимых работодателями с соискателями в режиме онлайн. В недалеком будущем оценка деловых и личных качеств соискателей при подборе персонала будет проводиться по видеосвязи с помощью нейронных сетей. Они же будут применяться и при анализе качества выполняемой сотрудниками работы для принятия кадровых решений -повышать, развивать, мотивировать, обучать, понижать или увольнять [10].

По мнению экспертов НИУ ВШЭ, будущее рынка труда - это сокращение офисных работников, снижение расходов на аренду помещений, переход от иерархически устроенных компаний к структурам более облачного типа или к схемам горизонтально устроенных компаний. Это акцент на контроль результата, а не процесса, а также упрощение трудовых соглашений.

С 1 января 2021 года вступил в силу приказ Минтруда России о существенном сокращении числа запрещенных для женщин профессии с 400 до 100 (цифры округлены). Теперь женщины могут работать, например, машинистами поездов, водителями фур, матросами и боцманами на речных и морских судах и т.д. Запрещенными остаются химические производства, подземные и горные работы, металлообработка, бурение скважин, нефтегазодобыча и ряд других*.

\section{Цифровизации рынка труда}

Важная роль в правительственном плане действий, обеспечивающих восстановление экономики, отводится цифровизации рынка труда. Речь идет о переходе на удаленный режим работы, совершенствовании режима неполной занятости и самозанятости, внедрении электронного кадрового документооборота и т.д.

По данным Минтруда РФ, если в конце 2019 года официально дистанционно работали 30 ты- сяч человек, то в октябре 2020 года уже в 116 раз больше - около 3,7 млн. (7\%) трудоустроенных граждан ${ }^{* * *}$.

Столь массовый переход работников на удаленную работу в результате действий против пандемии коронавируса остро поставил вопрос о коррекции трудового законодательства.

С 1 января 2021 года вступил в силу Федеральный закон от 08.12.2020 № 407-ФЗ «О внесении изменений в Трудовой кодекс Российской Федерации в части регулирования дистанционной (удаленной) работы и временного перевода работника на дистанционную (удаленную) работу по инициативе работодателя в исключительных случаях» ${ }^{* * * * *}$.

В ходе его разработки правительство и законодатели старались соблюдать баланс интересов работников и работодателей.

В законе выделены три категории дистанционной (удаленной) работы: постоянная, временная (до 6 месяцев) и комбинированная (чередование работы дистанционно и в офисе). Любая из них оформляется трудовым договором или дополнительным соглашением к нему.

Если раньше расторжение трудового договора с дистанционным работником по инициативе работодателя могло происходить по основаниям, изложенным в трудовом договоре, то теперь только по общим правилам, действующим для стационарных работников. Поэтому работодатели не смогут фиксировать в трудовых договорах удобные им условия их расторжения.

Ранее в Трудовом кодексе РФ прогулом считалось отсутствие на рабочем месте свыше четырех часов. При удаленной работе нет постоянного рабочего места, и за прогул можно уволить, если работник без уважительных причин не отвечает на запросы работодателя и не выходит на связь два рабочих дня. Также договор с удаленным работником можно расторгнуть, если он переехал в другую местность, из-за чего не может выполнять свои обязанности в полном объеме.

При переходе на удаленный режим работы должен сохраняться размер заработной платы сотрудника, если объем выполняемых обязанностей остается прежним.

Время взаимодействия дистанционного работника с работодателем теперь считается рабочим. Любое взаимодействие между ними за пределами рабочего времени оплачивается как

\footnotetext{
* https://mintrud.Rov.ru/docs/mintrud/orders/1366

** https .-//mintrud. gov.ru/employment/70

*** http://publ.ication.pravo.gov.ru/Document/View/000120201.2080Q47
} 
сверхурочное. Такое «право на офлайн» защищает дистанционных работников в случаях, когда работодатели нарушают баланс труда и отдыха, требуют постоянно быть на связи.

Также регулируются вопросы оформления отпусков, командировок, временной нетрудоспособности и т.д.

Законом предусматриваются максимальные возможности электронного кадрового документооборота с обоюдного согласия сотрудника и работодателя.

Внедрение электронного кадрового документооборота повышает эффективность кадровых служб предприятий, упрощает трудоустройство работников из других регионов, кадровую работу с сотрудниками региональных представительств крупных компаний, вахтовиков и т.д.

Минтруд России в октябре 2020 года начал эксперимент по переходу на электронный кадровый документооборот, который запланирован до 31 марта 2021 года. На портале «Работа в России» размещаются образцы кадровых документов, которые можно оформлены в электронном виде.

В настоящее время Минтруд России продол- жает работу над законопроектом по регулированию электронного кадрового документооборота*.

Одна из новых форма трудовых отношений быстро растущая платформенная занятость, которая связана с появлением электронных платформы («Алибаба», «Амазон», «Вайлдбериз», «Убер», «Яндекс такси», «Яндекс еда», «Деливери клаб», и другие). Это приводит к появлению новых продуктов и сервисов, а также к изменению и возникновению ранее неизвестных форм труда и профессий. В число работников, занятых цифровым фрилансом, входят и самозанятые, число которых увеличивается. Это требует организации сбора регулярной достоверной статистики для корректировки социальной политики и законодательного регулирования [2].

\section{Ожидания работников в условиях кризиса}

Бюллетень «Мониторинг экономической ситуации в России» опубликовал данные по ожиданиям работников, полученные в ходе телефонных интервью (объем выборки составил 1620 человек в возрасте от 18 лет и старше) (рис 3).**

* https://mintrud.gov.ru/employment/70

* Мониторинг экономической ситуации в России: тенденции и вызовы социально-экономического развития. 2021. № 1 (133). Январь / Под ред. Гуревича В.С., Дробышевского С. М., Колесникова А. В., Мау В.А., Синельникова-Мурылева С.Г.; Институт экономической политики имени Е.Т. Гайдара, Российская академия народного хозяйства и государственной службы при Президенте Российской

\section{Ожидания работников}

Оценка рисков потери работы в 2021 г.

как высокие - 23\% работников

как средние - $28 \%$ работников

При этом оченки рисков слабо связаны с возрастными различиями и практически одинаковые и у 35-54-летних, и у лиц в возрасте 55 лет и старие. Несколько ниже оценки риска потерять работу у молодежи до 35 лет.

\footnotetext{
Оценка фактора сложности в поиске новой работы с прежними условиями и зарплатой легко - лишь $21 \%$ работников трудно - $51 \%$ работников практически невозможно - $20 \%$ работников затрудняются ответить - 7\% работников

Молодежь более оптимистична е данном вопросе, тогда как более половины представителей стариих возрастов указывают на практически полную невозможность найти работу, похожую на прежнюю.
}

\section{Ожидания в части изменений заработной платы в следующем году у работников более позитивны} вырастет - $15 \%$ работников останется неизменной - 59\% работников снизится - $12 \%$ работников затруднились с ответом - $14 \%$ работников

Таким образом, основным риском на рынке труда с точки зрения работников стала угроза потери работы, которой они не смогут найти достойную замену. В то же время снижение заработных плат в суцественно меньией степени беспокоит российских работников. 


\section{Безработица}

Число безработных в выборке составило 9,5\% (154 человека), при том, что не все, кто определил себя безработными в данном опросе, являются таковыми с точки зрения официальной статистики, так как повседневное понятие «безработный» значительно отличается от термина в методологии МОТ (рис. 4).

\section{Восстановление рынка труда в 2021 году}

Выступая в конце января 2021 года на совещании Президента РФ с членами правительства, министр труда и социальной защиты А. Котяков назвал основные направления деятельности министерства, которые будут способствовать восстановлению российского рынка труда. Так, по всем субъектам Российской Федерации в региональных программах заложен почти 21 млрд. рублей на меры по восстановлению занятости. Дополнительными инструментами снижения напряженности на рынке труда должны стать федеральные программы по содействию занятости. *

Важной программой для восстановления рынка труда призван стать социальный контракт, который заключается органами социальной защиты с гражданами и семьями, име- ющими доход ниже прожиточного минимума. В рамках такого контракта орган соцзащиты населения оказывает различную помощь, в том числе денежную, а малоимущие граждане обязуются найти работу, пройти профессиональное обучение или заняться предпринимательством.

В рамках социального контракта предусмотрено комплексное решение вопросов трудоустройства для малообеспеченных граждан. Такую помощь смогут получать свыше 60 тысяч человек. Это и организация стажировок, и трудоустройство соискателей, находящихся в трудной жизненной ситуации. На федеральном уровне, по данным Минтруда России, предусмотрено переобучение в рамках национального проекта «Демография». Дополнительно востребованные на региональном рынке труда профессии смогут получить не менее 115 тысяч человек.

Наибольшие трудности в поиске работы испытывают граждане без профессионального образования. По состоянию на конец 2020 года $60 \%$ оставшихся без работы граждан не имели ни высшего, ни среднего специального образования. Это, как правило, те, кто были заняты неквалифицированным трудом, работали в сфере услуг. Таким гражданам сложно адаптироваться к изменяющейся ситуации на рынке

* http://www.mintrud.cap.ru/news/2021/01/29/doklad-ministra-truda-i-socialjnoj-zaschiti-rf-ant

\begin{tabular}{c} 
Изменения в составе безработных со времени второй волны опроса \\
в мае 2020 года - более трети респондентов потеряли работу в связи с пандемией \\
к сентябрю 2020 года эта доля сократилась до $14,4 \%$ \\
к декабрю 2020 года - вновь увеличилась до $19,9 \%$ в связи с негативными последствиями второй волны коронавируса \\
\hline
\end{tabular}

Половина всех безработных в выборке была занята в следующих четырех отраслях торговля - $18 \%$ стронтельство - $12 \%$

добыча полезных ископаемых и промышленность - $11 \%$ транспорт - $10 \%$

Изменения в отношении населения к пособиям по безработице
в случае потери работы будут оформлять пособие по безработице - $57 \%$ работающих респондентов (результат, заявленный
в декабре 2020 года, что не отличается от полученного в опросах в мае и сентябре)
значительно меняется доля фактически пытавиихся офорлить пособие
в мае 2020 г. $-18,1 \%$
в сентябре 2020 г. $-42,7 \%$
в декабре 2020 года - $36,4 \%$

Основные причины нежелания оформлять пособие

различные временные меры материальной поддержки населения, введенные весной-летом 20202. надежда быстро найти новую работу (доля респондентов, выбирающих такой вариант ответа, выросла с $38,7 \%$ в мае до $47,5 \%$ в декабре 2020 года)

иные источники суцествования и/или пособие незначимо по размеру (доля участников опроса, выдвигавших эти основания, немного снизнлась)

Тем не менее 55\% работников отмечают, что размер пособия был бы для них значимой или скорее значимой материальной поддержкой, что близко к результатам предыдуиих опросов 
труда самостоятельно, и у них нет возможности пройти дополнительное обучение за счет собственных ресурсов. Поэтому Минтруд России намерен осуществить дополнительные мероприятия по переподготовке. Набор программ будет формироваться под запрос рынка труда, т.е. по уже имеющимся вакансиям, а также по перспективным специальностям. Эта программа позволит дополнительно подготовить 54 тысячи человек.

Для достижения допандемических показателей необходимо трудоустроить миллион человек. Минтруд России предлагает расширить программу переобучения, ввести новые меры по субсидированию найма.

Субсидирование найма - это мера точечная, Минтруд России предлагает выделять работодателю субсидию в размере трех минимальных размеров оплаты труа при трудоустройстве граждан, которые были зарегистрированы в центрах занятости до 1 января 2021 г. Организация получит первый платеж через месяц после трудоустройства безработного гражданина, второй МРОТ - через три месяца, и третий - еще через три месяца.

Такие субсидии помогут организациям в адаптации новых сотрудников, имеющих длительный перерыв или перерыв в работе. Эти средства могут быть направлены на создание оборудования нового рабочего места, компенсацию расходов по наставничеству и другие расходы организации. Программа позволит трудоустроить свыше 220 тысяч граждан и станет одной из самых емких федеральных мер прямого действия.

В 2020 году Минтруд России составил «паспорт занятости», «портрет безработного» по каждому субъекту Российской Федерации, в котором отражены особенности каждого регионального рынка труда, а также детальный срез структуры региональной безработицы. Для каждого субъекта составлена индивидуальная адресная программа по восстановлению занятости с учетом территориальной специфики, которая будет способствовать восстановлению рынка труда.

\section{Реформа государственной службы заня- тости}

Пандемия Covid-19 и резкий рост безработицы подтолкнула исполнительную власть к мас- штабной реформе государственной службы занятости. Этот важнейший социальный институт в условиях кризиса оказался не готов ответить на вызовы пандемии и ее последствий.

Сайты многих центров службы занятости работали с перебоями, что снижало число обращений от людей, нуждающихся в поиске работы или персонала

В конце августа 2020 года газета «Ведомости» и компания Online Market Intelligence (OMI) опросили 4338 россиян - пользователей интернета, потерявших работу в 2020 году. Цель опроса: какую именно помощь в трудоустройстве им оказали органы занятости. Около двух третей выборки - люди, которые на прежнем месте работы имели заработную плату меньше 35 тысяч рублей*.

По данным опроса, 41,5\% оставшихся без работы в пандемию встали на учет в службах занятости. Остальные на учет не становились: либо справились с поиском работы сами, либо не верили, что им помогут. В частности, 38,7\% респондентов, не становившихся на учет, быстро нашли работу сами либо сменили место по собственному желанию. 38,4\% не видели смысла в таком обращении, еще 58\% не хотели заниматься сбором и заполнением документов. При этом 75,2\% зарегистрировавшихся в службах занятости сообщили, что это не помогло им найти работу. 16,1\% ответили, что нашли место с помощью службы занятости.

По данным опроса 25,2\% респондентов, ответили, что чиновники не помогли им с работой, поскольку не предложили вообще никаких вакансий, хотя их специальность востребована на рынке труда. Еще 14,6\% ответили, что служба занятости не предложила им никаких вариантов, потому что у нее в принципе нет вакансий для специалистов с такой высокой должностью, уникальной специальностью или высокой квалификацией, как у них. Еще 18,6\% сообщили, что им предложили вакансии, но они не соответствовали их специальности, должности на последнем месте работы или квалификации. А 9\% респондентов сказали, что им предложили вакансии, соответствующие их специальности и должности, но с нерыночной зарплатой. Большинство нашедших новое место с помощью служб занятости сказали, что устроились на зарплату выше, чем на предыдущем месте, или такую же (69,9\% респондентов), а 24,6\% заявили, что на новом

* https://www.vedomosti.ru/archive/2020/08/11 
месте потеряли в зарплате.

Причина столь низкой эффективности работы станет более понятна, если проанализировать 30-летнюю историю создания и функционирования службы занятости в постсоветской России. В этот период руководство государственными службами занятости было передано в регионы, и таким образом была нарушена вертикаль управления. В начале 2000 годов ликвидирован фонд занятости, прекращено страхование от безработицы и пособия безработным стали выплачиваться из бюджета, изменен социальный статус работников службы, что привело к массовому оттоку высококвалифицированных специалистов.

В 2020 году Минтруд России анонсировал масштабную реформу государственной службы занятости. Она предполагает трансформацию центров занятости в государственные кадровые агентства, которые должны стать экономическими агентами, способными оказывать реальную помощь как соискателям, так и работодателям.

Минтруд России в 2021 году уже начал работу по трансформации центров занятости в 61 регионе, которая завершится в 2023 г., когда на новый формат перейдут все российские центры занятости. Важно, что 22 тысячи сотрудников центров занятости пройдут переобучение, овладеют новыми компетенциями и современными технологиями.

Начата работа по созданию единой информационной платформы для всех центров занятости, чтобы максимальное количество услуг можно было предоставить в дистанционном формате и предлагать соискателям вакансии по всей стране.

Директор по развитию региональных проектов Всероссийского научно-исследовательского института труда (ВНИИ труда), эксперт МOT, экс-глава Роструда Юрий Герций рассказал порталу национальные проекты РФ, как в настоящее время ведется работа по масштабной модернизации служб занятости*.

Первое. Реформирование системы занятости - это длительный процесс. В таких масштабах реформа ранее не проводилась. И та работа, которая проделана на первом этапе в рамках нацпроекта «Производительность труда», заложила основу для дальнейшего движения вперед. C переходом в нацпроект «Демография» модернизация системы занятости приобрела новые смысловые акценты. Службы занятости станут важным инструментом для развития ранка труда и экономики страны. Ключевая задача - не просто формально казать ту или иную услугу, а решить проблему, с которой люди обращаются в центры занятости.

Второе. Определены несколько целевых групп, для которых прорабатываются комплексные решения,- это инвалиды, молодые мамы, подростки, выпускники и молодые специалисты, представители старшего поколения, граждане, желающие переехать в другой регион, бывшие заключенные. Сегодня они находятся в достаточно уязвимой позиции при трудоустройстве, т.к. работодатель зачастую оценивает сложившуюся ситуацию не в их пользу. Задача служб занятости - снять это предубеждение и создать всем соискателям равные условия. Для этого в региональных центрах занятости с учетом их запросов внедряются специальные пакеты услуг.

Третье. Современная служба занятости - это кадровое агентство, куда приходят не от безысходности, а для получения совета, новых компетенций, планирования карьеры и улучшения качества жизни. В центрах занятости будет аккумулироваться вся информация о региональном рынке труда, которая позволит делать прогнозы по кадровому потенциалу, заранее инициировать программы профессиональной ориентации и переподготовки. Такой подход может стать надежной основой для развития экономики регионов.

Четвертое. Сейчас в центрах занятости населения вместо системы традиционного разделения по кабинетам создают просторные общие пространства, чтобы посетители могли легко и быстро ориентироваться. Кроме того, запускаются электронные сервисы и внедряется единая цифровая платформа.

Пятое. В помощь специалистам службы занятости созданы решения и методические рекомендации, которые успешно прошли апробацию «на земле». Разработан единый реестр услуг и сервисов, в котором есть как отдельные услуги, многие из которых появились впервые, так и целые пакеты, сформированные по принципу жизненных ситуаций граждан и бизнес-ситуаций работодателей. Такие пакеты услуг можно расширять или видоизменять, добавляя из арсенала служб занятости новые элементы. Благодаря этому возможности оказания помощи значи-

* https://национальныепроекты.pф/search 
тельно расширяются. Кроме того, появятся дополнительные услуги, для оказания которых службы занятости будут заключать договоры со сторонними организациями. В их числе услуги по оказанию психологической помощи, организации работы «бебиситтеров», которые помогут мамам с малышами до устройства в детский сад, и другие.

Шестое. Изменятся взаимоотношения служб занятости с работодателями, которым до сих пор не уделялось должное внимание. Учреждения нового образца возьмут на себя часть работы кадровой службы предприятия по поиску сотрудников. Например, первичное интервью, определение потребностей работодателей в квалификациях и навыках под конкретные вакансии. За ключевыми работодателями региона будут закреплены персональные менеджеры.

Седьмое. Работа начинается с подробного мониторинга деятельности службы занятости, анкетирования клиентов, которые уже получали услуги,- и соискателей, и работодателей. То есть проводится внешний и внутренний аудит. Этим занимаются Минтруд России и Роструд. На этом этапе выявляются болевые точки, к которым, как правило, относятся отсутствие или нехватка подходящих вакансий, недостаточная квалификация соискателей и т.д. На основе анализа формируется план модернизации с конкретными мероприятиями по каждому региону.

Восьмое. Все центры независимо от своего статуса и степени модернизации уже сейчас работают в соответствии с новыми едиными требованиями. Это относится к регламенту работы (услуги должны оказываться быстро и в удобном формате), к оформлению помещений (комфортные, современные), а также к системе взаимодействия между ведомствами и другими организациями, например, образовательными.

\section{Планы совершенствования законода- тельства}

Ситуация на российском рынке труда в период пандемии актуализировала вопрос о скорейшем совершенствовании законодательства в сфере занятости.

В ноябре 2020 года руководитель рабочей группы по совершенствованию законодательства в сфере занятости населения Андрей Исаев рассказал об основных проблемах, над которыми работает рабочая группа, и какие изменения могут быть внесены в закон о занятости*.

1. Проблема безработицы достаточно остро встала в период пандемии, когда службам занятости удалось «переварить» огромный поток людей, вовремя назначить и начислить пособия по безработице. Тем не менее до $40 \%$ жалоб, с которыми граждане обращались в приемную партии «Единая Россия», были связаны со службой занятости. Проблема не в том, что она плохо работает, а в том, что закон «О занятости в Российской Федерации» существенно устарел. После принятия в 1991 году в него внесено 55 изменений, но в целом структура закона осталась прежней.

2. Необходимо существенно менять подходы в работу службы занятости населения, в частности, расширять онлайн общение. Полностью исключить личное общение между человеком и сотрудником службы занятости нельзя, потому что эта работа связана с психологией, выявлением творческого потенциала человека, его профессиональных навыков. Но многие вещи можно было бы перевести в онлайн, и это необходимо отразить в законодательстве.

3. Необходимо устранить излишне бюрократические процедуры. Сейчас для регистрации в качестве безработного нужно собрать 37 документов с подписями и печатями различных инстанций. Документооборот следует существенно сократить, тем более, что многие данные служба занятости может получить от коллег из налоговой службы или из Пенсионного фонда Российской Федерации.

По действующему законодательству, для того чтобы встать на учет в службе занятости и получить пособие, человек должен лично прийти в службу занятости, где он зарегистрирован по месту прописки. Зачастую это не совпадает с фактическим проживанием. Например, человек родился в Камчатке, уже 10 лет работает в Москве, но имеет камчатскую прописку, потерял работу и не может встать на учет в службу занятости в Москве. Ему нужно лететь через всю страну, чтобы стать на учет.

4. В работе над поправками особое внимание будет уделено индивидуальным предпринимателям и самозанятым. Сегодня они вообще выпадают из ведения службы занятости. Для того чтобы индивидуальные предприниматели зарегистрировались в качестве безработных, им требуется предоставить документы о прекраще-

* https://rg.ru/2020/10/06/isaev-vlast-planiruet-serezno-obnovit-zakony-rf-o-zaniatosti-naseleniia.html 
нии деятельности своих предприятий. Вопрос «зачем», если в дальнейшем рассчитываем, что они возобновят свою работу. Может быть достаточно информации налоговой службы о том, что они перестали получать доход, и это было бы основанием для того, чтобы начать с ними работать, выплачивать им соответствующие пособия.

5. Сегодня программы службы занятости делают упор на так называемые «общественные работы». Эти программы пора менять. Общественные работы в ситуации с занятостью болезнь не лечит: человек не приобретает никаких новых навыков, он просто занят на несколько месяцев, получает заработную плату, а через несколько месяцев вновь станет таким же безработным. Основной упор должен быть сделан на получение новой квалификации, на приобретение новых навыков, на регистрацию собственного дела, на поддержку переезда к новому месту работы. Именно эти сферы должны стать основными, а не организация общественных работ для службы занятости.

6. В ближайшее время депутатская рабочая группа внесет разработанный совместно с Минтруда России законопроект, который предлагает принять срочные меры: создание единого для всей России портала и расширение полномочий Федерации. Сегодня проблемами занятости в основном занимаются субъекты, и необходимо налаживать межрегиональные связи, организовывать потоки трудовых мигрантов внутри страны. Это будет фундаментальный законопроект в виде коренного изменения закона «О занятости населения в Российской Федерации» или его новой редакции.

7. Необходимо обсудить и принять окончательное решение о возможном переходе к страхованию безработицы, которое успешно действует во многих странах мира. Заинтересованным сторонам нужно договориться об общих принципах предоставления пособий, о создании дополнительных условий поддержки занятости таких уязвимых групп населения, как инвалиды или молодые специалисты, впервые ищущие работу.

В законопроекте, который в феврале 2021 года внесен в Госдуму, учтены следующие вопросы:

- службы занятости смогут принимать документы от соискателей как в очной форме, так и через Интернет. Это сокращает объем справок для того, чтобы встать на учет или оформить пособие по безработице;
- безработные могут регистрироваться на бирже труда не только по месту прописки, но и по месту фактического проживания. Особую поддержку в поиске работы получат молодые специалисты, инвалиды, бывшие заключенные. Начинающим предпринимателям службы занятости помогут открыть собственное дело, а пенсионерам - пройти профессиональную переподготовку;

- служба занятости будет общероссийской с отделениями в регионах. Запросы работодателей и соискателей со всей России объединят на едином для всей страны цифровом портале. Создание единой платформы в сфере занятости облегчит людям процесс трудоустройства. Когда все вакансии будут на одном ресурсе, легче найти работу, в том числе в другом регионе, что позволит стимулировать миграцию трудовых ресурсов внутри страны и сократить потребность в работниках из-за рубежа. Руководители, у которых в штате более 25 человек, обязаны размещать на этом сайте информацию о свободных рабочих местах;

- в законопроект внесена норма о финансовых стимулах для работодателей, которые берут на работу официально зарегистрированных безработных. Кроме того, предлагается возложить на службу занятости полномочия по координации политики в области трудоустройства с образовательной политикой.

Первый зампред Комитета Госдумы по труду и социальной политике Михаил Тарасенко отмечает: «Общественное обсуждение показало, что есть очень много предложений, большинство которых направлены на снижение бюрократии в работе служб занятости. На первом этапе поставлена задача закрепить то, что наработано в последний год в период пандемии».

Следующим этапом работы по совершенствованию законодательства о занятости может стать законопроект о страховании от безработицы, но эта тема для следующего созыва Госдумы.

Практические меры по восстановлению рынка труда в 2021 году, трансформация государственной службы занятости и совершенствование законодательства означают реальные шаги к новой политике в сфере занятости. Это должно способствовать построению единого, открытого и прозрачного рынка труда в России. Работа по построению такого более эффективного рынка труда может стать надежным фундаментом ускорения экономического роста. 


\section{Библиографический список}

1. Аналитическая записка: Сфера труда и COVID-19. Июнь 2020. OOH. URL: https://www.un.org/sites/un2. un.org/files/sg policv_brief/_world_of work and covid 19 russia n.pdf

2. Бобков В. Н., Черных Е.А.Платформенная занятость: масштабы и признаки неустойчивости. Мир новой экономики. 2020;14(2):6-15. DOI: 10.26794/2220-6469-2020-14-2-6-15. URL: https://wne.fa.m/jour/issue/ view/23/showToc

3. Будущее рынка труда 2020. Доклад Всемирного экономического форума (ВЭФ). 20 октября 2020./ The Future of Jobs Report 2020. The World Economic Forum, 20 October 2020. https://www.weforum.org/reports/the-futureof-jobs-report-202

4. Вестник Международной организации труда (MOT): COVID-19 и сфера труда. Шестой выпуск. Обновленные оценки и анализ. 23 сентября 2020. / ILO Monitor sixth edition: COVID-19 and the world of work. Updated estimates and analysis. September 23, 2020. URL: https://www.ilo.org/wcmsp5/groups/public/-europe/-гоgeneva/-sro-moscow/documents/briefingnote/wcms_756701.pdf

5. Доклад президенту России - 2020 об условиях ведения бизнеса в России уполномоченного по защите прав предпринимателей. URL: http://doklad.ombudsmanbiz.rU/2020/7.pdf

6. Королева А. Безработица подтолкнула к реформе службы занятости. Журнал «Эксперт». 26.11. 2020. URL: https://expert.ru/2020/1 1/26/bezrabotitsa-podtolknu.la-k-refo.rme-sluzhbi-zanyatosti/

7. Ляшок В.Ю.Новые технологии и рынок труда: роботы или люди. Сайт Econs. online. URL: https://econs. on1ine/articles/opinions/novye-tekhnologii-i-rynok-truda-roboty-ili-lyudi/

8. Ляшок В.Ю., Малева Т.М., Лопатина М. В. Влияние новых технологий на рынок труда: прошлые уроки и новые вызовы. Журнал «Экономическая политика». 2020. T. 15. No 4. C. 62-87. URL: http://ecpolicy.ru/images/ stories/2020 4/003.pdf

9. Маркина Н.А. Государственное регулирование экономики в условиях борьбы с COVID-19. Журнал «Экономика и бизнес: теория и практика». № 6 (64), 2020. URL: https://cyberleninka.ru/article/n/gosudarstvennoeregiilirovanie-ekonomiki-v-usloviyah-borby-s-covid-19

10. Прогноз рынка труда России 2021: работа после эпидемии. Сайт Онлайн школы IT рекрутера. URL: https:// it-recruitinR.ru/21-proRnoz-rynka-truda-rossii-2021-rabota-posle-epidemii/

11. Рабочая сила, занятость и безработица в России (по результатам выборочных обследований рабочей силы). 2020 Стат.сб./Росстат. М., 2020. 145 c. URL: https://rosstat.gov.ru/bgd/free/B99_ 1O/Iss WWW.exe/Stg/dO 10/ i010020r.htm

12. Российский рынок труда - 2020. Что будет? Институт профессиональных квалификаций. 18.06.2020. URL: https://www.anoipk.ru/novosti/Rossivskiy-rynok-truda-2020-CHto-budet

13. Российский рынок труда: тенденции, институты, структурные изменения. Доклад Центра трудовых исследований (ЦеТИ) и Лаборатории исследований рынка труда (ЛИРТ) НИУ ВШЭ. Под редакцией В.Гимпельсона, Р. Капелюшникова и С. Рощина. Москва. 2017. URL: https://irt.hse.ru/data/2017/03/21/1170068107/ Doklad_trud.pdf

14. Старостина Ю. Стагнация вместо выздоровления. «Ежедневная деловая газета РБК». 20.10.20. URL: https:// ww-w.rbc.ru/newspaper/2020/10/21/5f8eb6559a79471244b6dbfc

15. World Bank. 2020. Global Economic Prospects, June 2020. Washington, DC: World Bank. / Всемирный банк. 2020. Перспективы мировой экономики. URL: https://www.vsemirnvibank.org/ru/publication/global-economicprospects 